\title{
Udder Pathophysiology and Public Health
}

Riaz Hussain ${ }^{*}$, Muhammad Tariq Javed², Mehwish Faheem³ ${ }^{2}$ Zulfiqar Ahmed ${ }^{4}$, Mudassar Mohiuddin5, Muhammad Farhab $^{6}$, Iahtasham Khan ${ }^{7}$ and Khalid Mehmood ${ }^{8}$

${ }^{1}$ Department of Pathology, Faculty of Veterinary and Animal Sciences, The Islamia University of Bahawalpur, Pakistan ${ }^{2}$ Department of Pathology, Faculty of Veterinary Sciences, University of Agriculture, Faisalabad, Pakistan ${ }^{3}$ Department of Zoology, GC University, Lahore, Pakistan; ${ }^{4}$ Department of Food Science and Technology, Faculty of Agriculture and Environmental Science, The Islamia University of Bahawalpur, Pakistan; ${ }^{5}$ Department of Microbiology, Faculty of Veterinary and Animal Sciences, The Islamia University of Bahawalpur, Pakistan; ${ }^{6}$ College of Veterinary Medicine, Yangzhou University China; ${ }^{7}$ Section of Epidemiology and Public Health, University of Veterinary and Animal Sciences, Lahore, Sub-Campus Jhang, Pakistan; ${ }^{8}$ Faculty of Veterinary and Animal Sciences, The Islamia University of Bahawalpur, Pakistan

*Corresponding author: dr.riaz.hussain@iub.edu.pk

\section{INTRODUCTION}

Mastitis is an inflammatory disease of milk secretary tissues of animals, with relatively higher incidence among the disorders in milch animals. Mammary glands infection results in production loss to dairy industry (DeVliegher et al. 2005; Bachay et al. 2011; Ali et al., 2016).

Bacterial pathogens are most prominent infectious agents throughout the world (Bradley 2002; Unnerstad et al. 2009). Mastitis is caused by a wide range of bacteria, mainly Staphylococcus aureus and Corynebacterium species. It severely affects milk quality and production of infected animals and has tendency to spread rapidly within the herd and to other animals. Compositional changes in milk of infected animal with mastitis depend upon inflammatory response of mammary glands, extent and pathogenicity of infectious agent, along with amount of infected tissue, leakage of blood, various enzymes, proteins, salts, decreased concentration of lactose and fat in milk (Kitchen 1981; Osteras 2000; Eckersall et al. 2001).

Mastitis is linked with enzymes, as lactate dehydrogenase and alkaline phosphatase enzymes are increased in milk from animals infected with subclinical mastitis, which is mainly due to tissue damage provoked by subclinical mastitis (Batavani et al. 2007). Mastitis is also linked with minerals, as the milk $\mathrm{pH}$, sodium content, electrical conductivity and malondialdehyde concentration is higher, while the concentrations of other minerals like calcium, zinc, iron, magnesium, potassium and phosphorus are decreased in mastitic animals (Mehrzad et al. 2002).

Shape of udder, asymmetric udder with larger rear quarters than front quarters, udder injuries, udder oedema, housing, feeding, breed and management have been known as mastitis risk factors (Schukken et al. 1994; Slettbakk et al. 1995; Waage et al. 2001; Svensson et al. 2006; Compton et al. 2007). Mastitis has great economic importance, as it may lead to the culling of affected animals. In dairy production, improved management and different control measures have greatly decreased the incidence and prevalence of contagious mastitic organisms. Inflammation of mammary tissue (mastitis) is a multifarious disease that affects dairy animals and causes huge economic losses in the form of decreased milk yield (3-5\%) and impairs milk quality which indicates serious risk for human health (Costa 1998; Marjan et al. 2009).

\section{Mastitis}

Mastitis is an inflammatory disease of milk secretary tissues of animals, with relatively higher incidence among the disorders in milch animals. Mammary glands infection results in production loss to dairy industry (DeVliegher et al. 2005; Bachay et al. 2011). It affects the milk quality and is also hazardous from the public health prospective. It also leads to an increased culling rate of affected animals from the herd (Parker et al. 2007). It is a multifactor disorder. The disease occurs when pathogens penetrate the teat orifice, enter into the mammary gland and thrive in udder, causing its inflammation (Pacha et al. 2020).

Clinical mastitis exhibits systemic reaction of mammary parenchyma, discoloration of udder, hardened quarters, abnormal secretions, flakes and clots in milk and loss of appetite of the affected animal (Akers and Nickerson 2011). On the other hand, sub-clinical infection without showing clinical picture remains vague to dairy animals. Increase in milk somatic cell count is typical finding in subclinical mastitis (Schwarz et al. 2020). Subclinical mastitis can be diagnosed by culturing of bacteria from milk, but routinely it is not a good test (Hamann 2002 and Akersted et al. 2007; Pyorala 2009).

\section{Mammary gland}

Mammary gland is a complex organ by both in configuration and function. Milk is sterile and free from pathogens when it is secreted by the mammary gland and is infected with different microorganisms when flows out of the udder. Milk production is a complex process and is under the influence of hormones and some other factors which affect milk yield (Silanikove et al. 2006). Generally, various pathogenic and non-pathogenic microorganisms cause changes in colour, taste and aromas of milk and 
certain pathogens result in food borne diseases. Pathogenic organisms which are responsible for deterioration of milk and its products quality mainly enter milk through improper milking, handling, storage and finally unhygienic condition of employee.

Bovine mammary gland is highly susceptible to new intramammary infections around calving, and many infections which occur at this stage result in clinical mastitis. Histological examination of infected mammary glands demonstrates a severe inflammatory response. It has been suggested that marked leukocyte infiltration is harmful to the mammary tissues (Nickerson 2009).

\section{Etiology and Microbiology}

Bacterial pathogens are most prominent infectious agents throughout the world (Bradley 2002; Unnerstad et al. 2009). Mastitis is caused by a wide range of bacteria, mainly Staphylococcus aureus and Corynebacterium species. Streptococcus dysgalactiae acts as an environmental pathogen (Ali et al. 2008; Unnerstad et al. 2009; Waller et al. 2009; Fakhar-uz-Zaman et al. 2009; Ibrahim et al. 2011). Mastitis causing bacteria are divided into two groups, as Gram positive and Gram-negative bacteria based on Gram staining, with Gram-positive bacteria withhold crystal violet stain and Gram-negative bacteria lack peptidoglycan layers and teichoic acid is incorporated within the peptidoglycan. The major Gram-positive bacteria include Staphylococcus aureus, Streptococcus dysgalactiae, Streptococcus uberis and Streptococcus agalactiae (Piepers et al. 2009). Among Gram negative mastitis pathogens, E. coli acts as the primary pathogen which causes mastitis in dairy herds (Piepers et al. 2009; Djabri et al. 2002; Unnerstad et al. 2009).

Among a wide range of pathogens causing mastitis in buffaloes and cows, Staphylococcus aureus and Streptococcus agalactiae are the most frequent etiological agents and induce extensive and wide variety of pathologies in lactating animals (Djabri et al. 2002; Wilson et al. 2004; Marjan et al. 2009; Cheng et al. 2010).

Staphylococcus aureus is the major pathogen identified worldwide (Guler et al. 2005; Pyorala and Taponen 2009). Mastitis caused by Staphylococcus aureus is a highly contagious disease (Bachay et al. 2011). In dairy animals, Staphylococcus aureus causes hardness of udder (Nagase et al. 2002; Soliman 2018). Staphylococcus aureus infection also forms abscesses in mammary glands. These occluded areas become refractory to antibiotics (Pacha et al. 2020).

Staphylococcus chromogenes, Staphylococcus hyicus and Staphylococcus aureus are the common pathogens isolated from secretion and teat canal keratin. Isolation of Staphylococcus aureus is linked in tie stalls and Streptococcus dysgalactiae are associated with teat injuries (Unnerstad et al. 2009). Intra-mammary infections with Staphylococcus aureus may result in clinical or subclinical mastitis and is usually associated with increase in somatic cell count. Staphylococcus aureus is a problem under different field conditions. This pathogen is contagious. So, control of Staphylococcus aureus mastitis remains important and necessary (Waller et al. 2009). Phenotyping and genotyping techniques have been developed for $S$. aureus isolates, such as gene typing (Wang et al. 2009), and amplification of specific gene regions (Javid et al. 2018; da Silva Soares et al. 2021). Histological and molecular studies are, therefore, valuable tools in assessing the damage caused by mastitis pathogens to secretory tissue of the udder in bovine mastitis.

\section{Immune cells and Somatic Cell Count}

\section{Udder Lesions}

The risk of increased milk somatic cell is higher in animals with increased udder lesions, along with increasing amounts of concentrates in feed, moving animals to confined housing before the calving day and use of restraint procedures at milking (Svensson et al. 2006). Other risk factors for clinical and subclinical infection are dirty udder after calving, udder edema and breed immunity/predisposition (Compton et al. 2007).

The movement of polymorphonuclear leukocytes during inflammatory process, triggered by clinical and subclinical mastitis pathogens, is crucial against infections (Sordillo 2018; Fakhar-uz-Zaman et al. 2009; Abera et al. 2010). The measuring of milk somatic cell count is the standard way for diagnosis of subclinical mastitis, along with various other inflammatory tools like electrical conductivity, enzymes and proteins (Hamann 2002 and Akerstedt et al. 2007; Pyorala 2009).

\section{Intra-Mammary Infectious Agents and Somatic Cell} Count

Coagulase-negative Staphylococci are the cause of higher percentages of milk leukocytes and damage the mammary parenchyma (Pyorala and Taponen 2009). Intra-mammary infections with Staphylococcus aureus are associated usually with increased milk somatic cell count. S. aureus remains a problem in a variety of locations and under different management conditions. This pathogen is contagious and spreads easily within dairy herds (Barkema et al. 1999; Barkema et al. 2006; Marjan et al. 2009). Milk somatic cells consist of macrophages, neutrophils, lymphocytes and epithelial cells (Lindmark-Mansson et al. 2006; Fakhar-uz-Zaman et al. 2009).

Staphylococcus aureus cause both clinical and subclinical mastitis, which increases milk somatic cell count (Taponen and Pyorala 2009). When somatic cell count increases in milk, a decrease in proteins together with breakdown and less absorption of calcium occur in milk from animals infected with clinical or subclinical mastitis. Milk somatic cell counts are usually used as diagnostic tool. The mean somatic cell count in healthy buffaloes is $3.64 \times 10^{5}$, while in cattle it is $3.40 \times 10^{5}$, while in mastic animals these values are 62.69 and $41.34 \times 10^{5}$, respectively (Shah et al. 2017; Kirkeby et al. 2021; Leitner et al. 2000a; Pillai et al. 2001; Moroni et al. 2005; Dhakal 2006; Lindmark-Mansson et al. 2006; Suriyasathaporna et al. 2006 Piepers et al. 2009; Fakhar-uz-Zaman et al. 2009). 


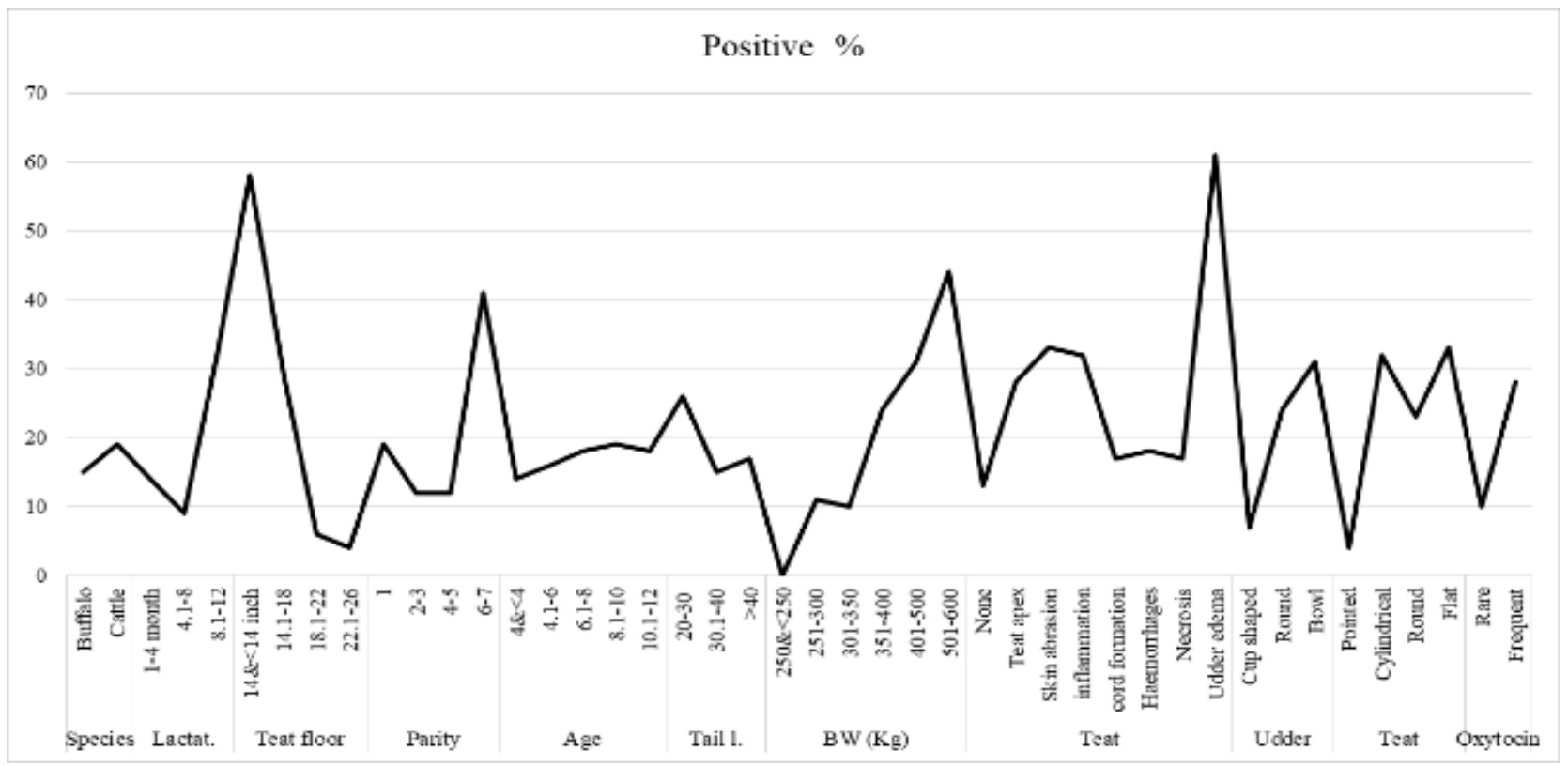

Table 1: Overall bivariate frequency analysis of different parameters in infected and healthy cattle and buffaloes to CMT test (Hussain 2011).

Staphylococcus aureus cause both clinical and subclinical mastitis, which increases milk somatic cell count (Taponen and Pyorala 2009). When somatic cell count increases in milk, a decrease in proteins together with breakdown and less absorption of calcium occur in milk from animals infected with clinical or subclinical mastitis. Milk somatic cell counts are usually used as diagnostic tool. The mean somatic cell count in healthy buffaloes is $3.64 \times 10^{5}$, while in cattle it is $3.40 \times 10^{5}$, while in mastic animals these values are 62.69 and $41.34 \times 10^{5}$, respectively (Shah et al. 2017; Kirkeby et al. 2021; Leitner et al. 200oa; Pillai et al. 2001; Moroni et al. 2005; Dhakal 2006; Lindmark-Mansson et al. 2006; Suriyasathaporna et al. 2006 Piepers et al. 2009; Fakhar-uz-Zaman et al. 2009).

Some pathogens release metabolic by-products, or toxins when they enter and multiply in the mammary tissue. These factors are released either directly or indirectly by different pathogens that serve as chemotactants for the leukocytes (Âvila et al. 2020). If somatic cells move rapidly from the blood vascular system and can reduce the inflammatory stimuli (pathogens), then further movement of leukocytes stops, and somatic cells number returns to physiologically normal level. However, when the pathogens can survive after the immediate host response, then the inflammatory process continues, resulting in increased somatic cell migration between the mammary secretary cells towards the alveolar lumen (Capuco et al. 2003).

Mastitis severely affects milk quality and production of infected animals and has tendency to spread rapidly within the herd and to other animals. Compositional changes in milk of infected animals with mastitis depend upon inflammatory response of mammary glands, extent and pathogenicity of infectious agent, along with amount of infected tissue, leakage of blood, various enzymes, proteins, salts and decreased concentration of lactose and fat in milk (Adkins and Middleton 2018; Osteras 2000; Eckersall et al. 2001).
Mammary infections reduce income from dairy animals. Various environmental and individual risk factors including milking technique, hygienic husbandry practices and use of antibiotics to treat mastitis during dry period and lactating stage relate to mastitis (Bradley and Green 2001). Different strategies including selection of those animals which have resistance against the disease, removal of animals which are susceptible to disease and environmental hygiene can be used to lower the prevalence of mastitis.

More than $90 \%$ of the total somatic cells which come from blood into mastitic milk are the neutrophils (Depreester et al. 2017). Somatic cells act as natural defence mechanism and first line of defence against invading pathogens in the mammary gland and include eosinophils, monocytes, lymphocytes, macrophages, neutrophils and a few epithelial cells (Riollet et al. 2000; Pillai et al. 2001; Hussain et al., 2012). Milk somatic cells reflect inflammatory process in the udder of infected animals during infection and initiate the immune system. Milk somatic cell count is a golden standard and quick tool to measure inflammation by cytological investigation and is directly related to immune system of mammary gland triggered by different pathogens (Riollet et al. 2000; Leitner et al. 2007). Milk somatic cell count also increases with increase in stage of lactation. Occurrence of increased leukocytes in milk samples is indicative of presence of subclinical infection. Quarters with somatic cell count greater than 200,000 per $\mathrm{ml}$ are at the greatest risk of clinical mastitis (Green et al. 2004; Dhakal 2006; Suriyasathaporna et al. 2006; Paape et al. 2007; Gargouri et al. 2008).

\section{Milk production and leukocytes}

Milk production is decreased as the population of milk leukocytes increases in animals (Pacha et al. 2020; Piepers 
et al. 2009). The milk production is also dependent on parity, breed and lactation stage of cattle (Durr et al. 2008).

The mammary parenchymal DNA content is higher before calving and localization of thymidine in mammary tissue is more in dry cows than in lactating animals (Fabris et al. 2020). Administration of bovine somatotropin (bST) increases mammary epithelial cells, showing nuclear proliferation during mid-lactation stage. The number of mammary epithelial cells within the mammary gland decreases with increase in lactation stage, indicating the loss of milk production along with increase in mammary cell apoptosis (Capuco et al. 2003).
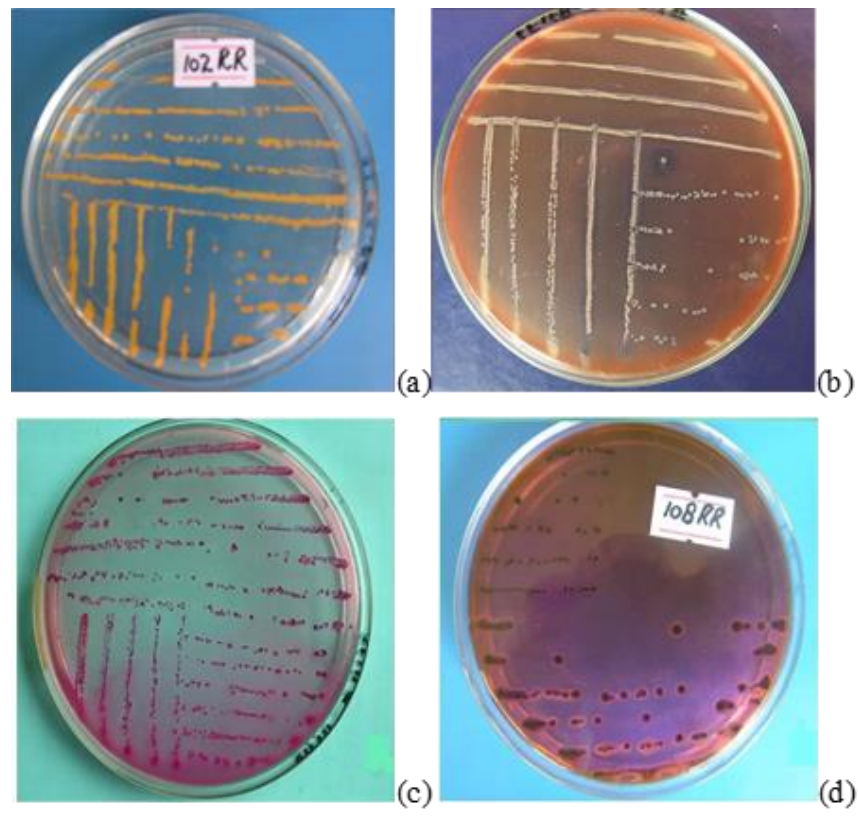

Figure 1: (a) Creamy white to yellow and golden colonies of $S$. aureus on Staph 110 agar medium, (b) Small pin point colonies of Streptococcus agalactiae on 5\% sheep blood agar medium, (c) Rose pink colonies of E. coli on MacConkey's agar (A) and metallic shin on EMB agar (D) isolated from cattle and buffaloes (Hussain 2011).

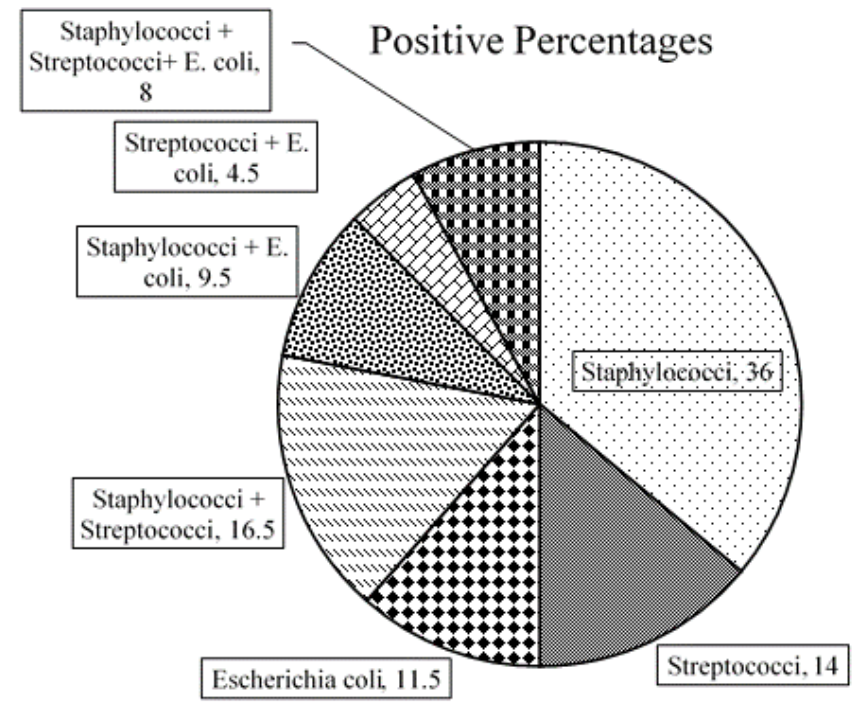

Figure 2: Overall prevalence of different pathogens recovered from mastitis animals at abattoir (Hussain 2011).

\section{Free radicals, Enzymes and Hormones}

Free radicals of mastitis cause damage to mammary glands and decrease the milk production (Moradi et al. 2020). The secretion of milk and proteins in udder by secretory cells is controlled by several systemic and multiple steroid hormones (Suriyasathaporna et al. 2006; ELsayed et al. 2009; Ibrahim et al. 2011; Cardoso et al. 2020).

Mammary glands infected with algae indicate inflammatory response, along with mononuclear infiltration of eosinophils and polymorphonuclear cells (Benites et al. 2002). Staphylococcus chromogenes and Staphylococcus epidermidis decrease milk production due to damage in udder tissues and increased connective tissue stroma (Santos et al. 2009). Cows infected with Brucella show hyperplasia of mammary lymph nodes and medullary plasmacytosis, with infiltration of lymph nodes with macrophages (Beytut et al. 2009). The total milk somatic cell and neutrophil counts are higher in mastitic than healthy animals. However, the percentages for macrophage and lymphocytes are lower in milk of mastitic than healthy animals.

When the mammary gland is invaded by pathogenic bacteria, these cells gather in the udder to decrease microorganisms under the effect of various cell communication products (Piepers et al. 2009; Damm et al. 2017; Malik et al. 2018). The inflammatory process of mammary tissue is directly related to influx of neutrophils. In the mammary gland alveoli, neutrophils produce and release toxic chemicals which lead to decreased milk production and are termed as somatic cells.

\section{Mastitis and Enzymes}

Streptococcus dysgalactiae invasion does not influence the mammary epithelial cells viability and is dependent on specific time. Cellular damage is indicated by localization of higher amount of lactate dehydrogenase (Oliszewski et al. 2002; Chen et al. 2021). Lactate dehydrogenase and alkaline phosphatase enzymes are increased in milk infected with subclinical mastitis due to tissue damage provoked by subclinical mastitis (Batavani et al. 2007). Overall activities of enzymes in sheep mammary tissues are higher than in cattle. The activity of glucose-6phosphate dehydrogenase, lactate dehydrogenase, and oxidoreductases are increased in all animals. In cells of ducts and secretory cells, glucose-6-phosphate dehydrogenase shows higher concentration but lower values in cells of the interstitium. The activity of both enzymes, glycerophosphate dehydrogenase and succinate dehydrogenase, are reduced in sheep and cattle. Alkaline phosphatase and ATP-cleaving enzymes have strong activity in duct cells and lactiferous ducts of mammary gland, respectively (Manocha et al. 2017). Staphylococcus aureus isolates from infected animals are positive for deoxyribonuclease and mannitol fermentation (Arshad et al. 2006). The level of various milk fractions, including sodium, chlorine, milk $\mathrm{pH}$, milk albumin, milk lactate dehydrogenase and immunoglobulin, are increased in infected quarters as compared to healthy quarters. Milk 

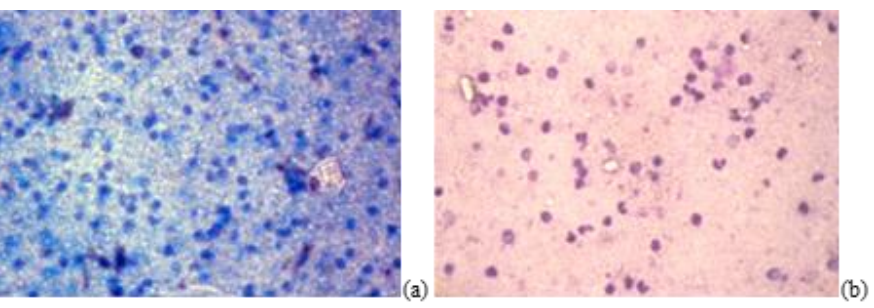

Figure 3: Somatic cells stained with; (a) Newman lampert stain, (b) Giemsa stain from milk sample of cattle and buffaloes (Hussain 2011).

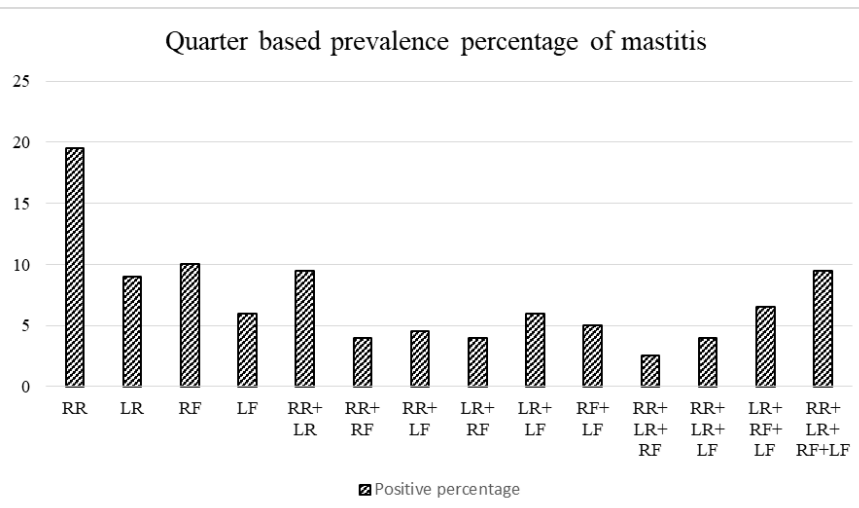

Figure 4: Overall quarter based prevalence of mastitis in animals studied at abattoir. RR, LR, RF and LF means right rear, left rear, right front and left front, respectively (Hussain 2011).
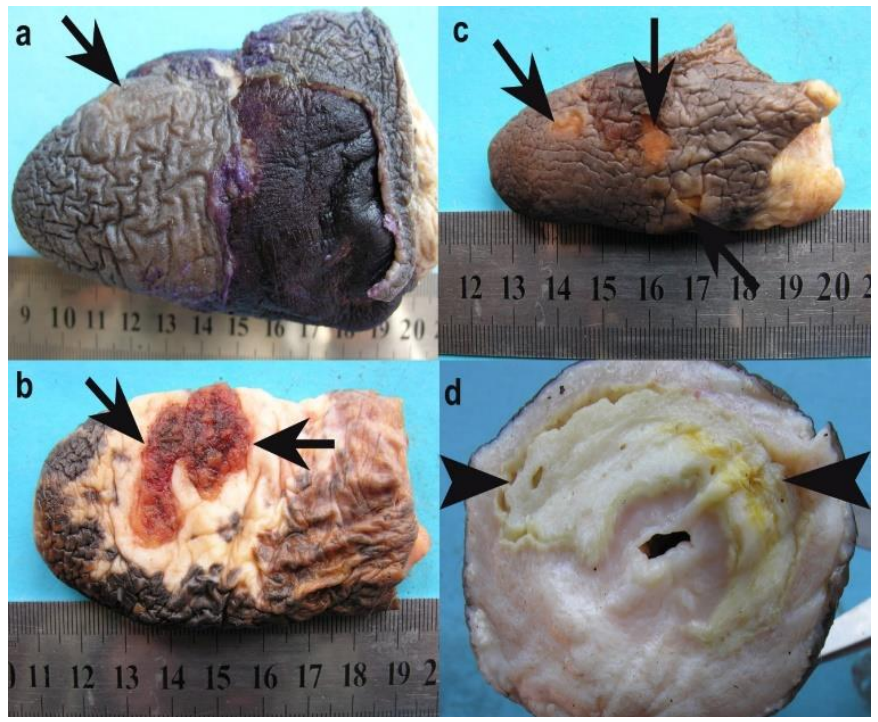

Figure 5: Various gross lesions: Inflammation (a), necrotic tissues (b, c) and fibrosis (d) in cattle and buffaloes (Hussain 2011).

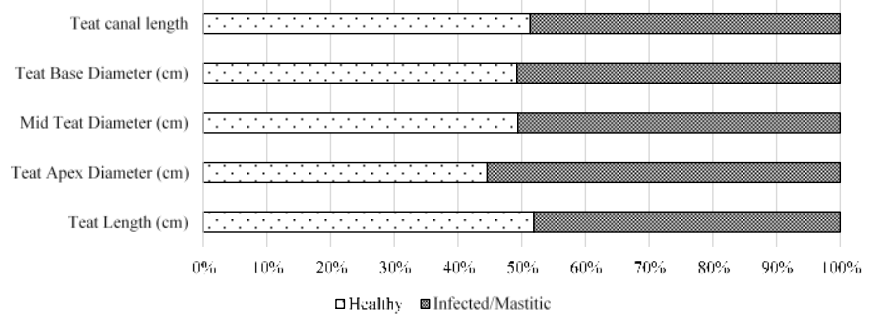

Figure 6: Measurements (Mean \pm SD) of various parts of teat (Hussain 2011).

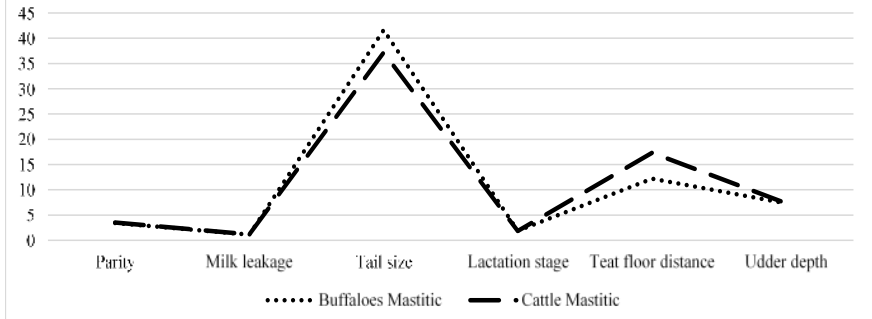

Figure 7: Analysis of various physical parameters of infected and healthy buffaloes and cattle at various livestock farms (Hussain 2011).
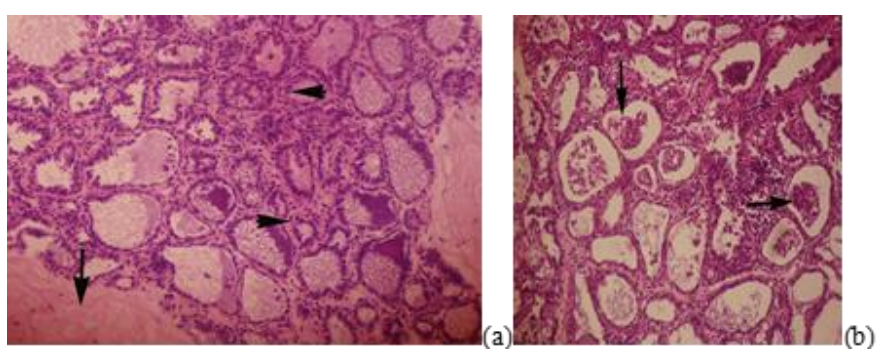

Figure 8: Section of mammary tissue showing; (a) cellular infiltration, increased stromal tissue (arrow) and atrophy of alveoli, (b) severe cellular exudate and infiltration of mononuclear cells (arrow). 200X, H \& E Stain (Hussain 2011).

phosphorus, calcium and beta-lactoglobulin are decreased in infected quarters (Batavani et al. 2007). There is increased malondialdehyde in blood and milk of animals infected with sub-clinical and clinical mastitis (Kumar et al. 2007).

\section{Histochemical Studies}

The activity of an alkaline phosphatase in cattle and buffaloes, which are not infected with mastitis, is on the outer boundary of alveolar secretary cells presenting cellular activity. Tissue sections of infected animals show weak alkaline phosphatase activity (staining) on the outer membrane. In most of the infected tissues, activity of this enzyme is low, negligible or altogether absent. There is high protein staining density in tissue sections of noninfected cattle and buffaloes. However, the tissue sections of infected animals show low to absence of protein.

\section{Mastitis and Minerals}

The milk $\mathrm{pH}$, sodium content, electrical conductivity and malondialdehyde concentration are higher, while the concentrations of other minerals like calcium, zinc, iron, magnesium, potassium and phosphorus are lower in mastitic animals. There is a difference in various enzymes including lactate dehydrogenase and alkaline phosphatase in milk of buffaloes and cattle. Performance of dairy industry is negatively affected the poor management, reduced nutrition and different diseases. Adequate mineral supplementation optimizes immune system function by reducing various metabolic and oxidative pressures and play crucial role in the defence mechanisms of mammary glands against mastitis. In modern dairy 


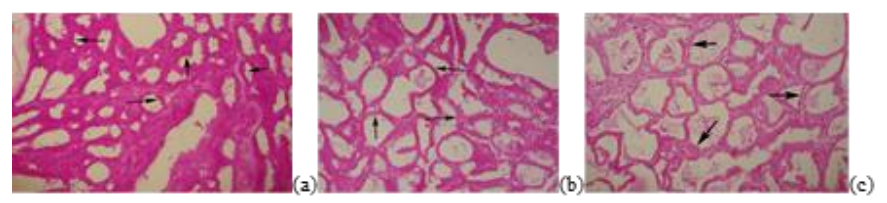

Figure 9: Section from mammary gland showing (a) high, (b) weak, and (c) no level of alkaline phosphatase activity (arrow). 200X (Hussain 2011).

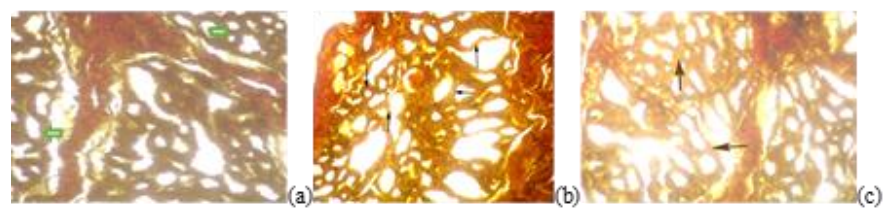

Figure 10: Section in mammary tissue showing (a) high protein staining, (b) low protein staining, and (c) negligible protein staining, all separated by trabeculae of connective tissue (arrow). 200X (Hussain 2011).

industry, animals face physiological stress when they move from the burden of foetal growth to calving, production of colostrum and milk. Suitable physiological environment is crucial for the repair process of tissue damaged during disease condition. Physiological stress at the time of transition stage favors mastitis and metritis. Various minerals play important role in reducing disease challenges and oxidative reactions (Mehrzad et al. 2002). Dietary minerals including $\mathrm{Zn}, \mathrm{Cu}$ and Se play special role in ensuring efficient growth, and reduced milk somatic cells (Griffiths et al. 2007; Cortinhas et al. 2010).

Organic mineral supplementation can affect health of mammary glands and milk yield; while marginal or low levels of minerals increases the risk of mastitis and different other diseases (Ashmead and Samford, 2004; Enjalbert et al. 2006). When mastitis occurs, free radicals are released during the process of phagocytosis, which cause decrease in milk production and mammary gland lesions. Various minerals, including $\mathrm{Zn}, \mathrm{Cu}$ and $\mathrm{Se}$ supplementations, have been associated with higher antioxidant activity, resulting in reduced somatic cell count and increased quantity of milk in dairy animals (Kellogg et al. 2004; Griffiths et al. 2007; Qayyum et al., 2016).

\section{Mastitis and electrical conductivity}

There is increased electrical conductivity in Staphylococcus aureus infected quarters, having high somatic cell count compared to non-infected animals (Khatun et al. 2019), due to its high salt content (Mabrook and Petty 2003). Mastitis increases the electrical conductivity and $\mathrm{NaCl}$ concentrations of milk (Stocco et al. 2020).

\section{Mastitis and Risk factors}

Different risk factors, including shape of udder, asymmetric udder with larger rear quarters than front, udder injuries, udder oedema, housing, feeding, breed and management, have been known as mastitis risk factors (Waage et al. 2001; Svensson et al. 2006; Compton et al.
2007; Okkema and Grandin 2021). Many risk factors of mastitis related to environment, the microflora and the animal have been investigated in spite of wide control efforts without encouraging results; however, the bovine mammary gland infection (mastitis) is a frequent and important problem among livestock herds in most of the countries world-wide. The occurrence of mastitis is influenced by managemental and different environmental factors, like housing of animals, type of milking and milking utensils, type of feeding, hygienic quality of water, health of lactating animals and execution of various preventive procedures. There is a positive correlation between clinical mastitis and udder balance, depth of udder and its attachment in different dairy animals (Sorensen et al. 2000; Zavadilová et al. 2020). Disease record, genetic and morphological investigations are crucial and efficient approaches to raise disease confrontation in animal population. Various morphological characters related to udder health play an important role and may affect susceptibility for mastitis.

Teats

All the efforts right from insemination to the lactation of animals become futile due to the infection of the mammary glands culminating in mastitis. Knowledge about pathogenic condition of milk and various structures of udder is of great value in understanding the process of mastitis in animals. The teat canal remains opened for 2 hours after milking and pathogens may reach the mammary gland through the teat canal to establish the infection. The severity of inflammatory response is dependent both upon the pathogen and host factors. The pathogens factors include the species, virulence, strain, and size of inoculums of bacteria, whereas the host factors include parity, stage of lactation, age and immune status of animals. Pathological changes soon develop in the teat and udder, reducing production potential of the animal and bringing about change in the quality and quantity of milk. Small pockets of fibrous tissue cause atrophy, replace and reduce the glandular parenchyma, making difficult for antibiotics to reach and also prevent complete removal of milk. The animal soon loses its utility as a milking animal and is finally considered suitable for beef purposes. Histopathological sections from various infected teat tissue indicate inflamed mucosa, teat polyps and fibropapiloma (Misk et al. 2018). In spite of growth inhibitory properties of keratin, bacteria are able to survive in teat canal, causing inflammation (Moroni et al. 2006; Oviedo-Boyso et al. 2007 and Ibrahim et al. 2011; Pacha et al. 2020). Animals with unbalance gland, flat and wide teat-ends, milk dropping and increased milk flow are more susceptible to intra-mammary infections. It has been reported that pathogens gain entry through teat orifice with the presence and morphology of teat injuries play a crucial role in the pathogenesis of mastitis (Chrystal et al. 2001; Okkema and Grandin 2021). There is a positive correlation between prevalence of clinical mastitis and teat length (Sorensen et al. 2000; Zavadilová et al. 2020). 


\section{Teat Shape}

Shape of teats, milk leakage from teats, pointed teats, lower teat end to floor distance and increased teat canal diameter have been known as mastitis risk factors (Waage et al. 2001; Svensson et al. 2006; Compton et al. 2007; Bhutto et al. 2010; Okkema and Grandin 2021). Funnelshaped teats had lower incidence of mastitis as compared to cylindrical-shaped (round) teats. It is difficult to explain why mastitis is higher in animals having cylindrical or round teats than those with other teat shapes. Further studies are needed to confirm it and to find the association of anatomical variations which help the pathogens to gain entry or be retained in teat canal or cistern and not cleared while milking (Sorensen et al. 2000; Waage et al. 2001; Svensson et al. 2006; Compton et al. 2007; Derakhshani et al. 2020). Teat-end shape has lower effect on milk somatic cell count than period of calving and parity of animals (Chrystal et al. 2001). Regarding teat shape, flat and round teats show higher susceptibility of mastitis than pointed teats. Animals with larger hindquarter shape have less Streptococcus uberis, Staphylococcus aureus and E. coli infection. Streptococcus dysgalactiae and Streptococcus agalactiae infections are higher in cattle with large pendulous udder (Bhutto et al. 2010). The prevalence of mastitis is higher in animals having round or bowl-shaped udder than those having cup shaped udder.

Mastitis, and Length and Diameter of Teats and Udder

Strong association has been found for the incidence of mastitis and teat diameter instead of milk yield (Guarín et al. 2017). Prevalence of mastitis both in buffaloes and cows is higher in quarters with small teat length, streak canal length and large teat diameter (apex, middle, and base) (Sorensen et al. 2000; Klaas et al. 2004; Bhutto et al. 2010; Guarín et al. 2017; Talukder and Ahmed 2017; Tiezzi et al. 2020; Tiezzi et al. 2020; Zavadilová et al. 2020; Derakhshani et al. 2020; Okkema and Grandin 2021). Mastitis can occur in cattle and buffaloes at advanced stages of lactation, which may be linked with continuous milking of animals for long time, putting pressure on teats, which results in breaks in epithelial lining and thus causes mastitis. Teat canal length is lower in mastitic than healthy buffaloes, while teat apex diameter, mid teat diameter and teat base diameter are higher in mastitic than healthy animals.

\section{Oxytocin and Calves used for Milk Let Down}

Prevalence of mastitis is higher in animals in which oxytocin is frequently used for milk let down. It may be due to the fact that oxytocin increases smooth muscles contraction of teat and teat cistern, ultimately ballooning of these tissues is resulted, the teat sphincter remains open for more time and in this way pathogens get chances to enter the mammary glands. Prevalence of mastitis is also increased in cattle and buffaloes in which calves are used for milk let down (Derakhshani et al. 2018; Ashraf and Imran 2020). It is also associated with teat lesions (Hultgren, 2002; Gleeson et al. 2004; Svensson et al. 2006; Compton et al. 2007; Nyman et al. 2007; Breen et al. 2009; Cerqueira et al. 2018).

\section{Housing Circumstances, Sanitation, and Milking}

Teat disinfection after milking with a low milk leukocytes count is positively associated with the incidence of clinical udder infection. The incidence of clinical mastitis due to Escherichia coli is associated with housing circumstances, sanitation, and machine milking. Staphylococcus aureus infection is related to milk somatic cell score, while the incidence of clinical mastitis caused by Streptococcus dysgalactiae and Streptococcus uberis is correlated to housing, diet, and machine milking (Tomazi et al. 2018). Other risk factors for clinical and subclinical infection are low teat height above the ground, dirty udder after calving, udder edema and breed immunity (Compton et al. 2007). Full-hand method of milking and teat dipping are not correlated with incidence of mastitis (Lakshmi et al. 2009).

\section{Mastitis and Teat quarter involvement}

Some relationship has been found in hyperkeratotic teat injures and udder shapes of infected animals. A strong association was observed between intra-mammary pathogens including Staphylococcus aureus, S. uberis, coagulase-negative Staphylococci, S. agalactiae and E. coli and the presence of hyperkeratotic teat injuries at calving (Bhutto et al. 2010). Various morphological characters related to teats play important role and may affect susceptibility of mastitis. There is higher association among various traits including location of teat (front/rear), teat length, teat morphology, teat end shape and teat canal eversion, harsh teat canal eversion, teat canal eversion and rough/cracked teat canal, teat canal eversion and teat end edema are associated with prevalence of mastitis (Wieland et al. 2020). Involvement of right rear, right front quarters, and right rear + left rear quarters has higher percentages of infection. Intramammary infection originating in dry period reduces milk production by about $35 \%$ compared with uninfected quarters (Bhakat 2019). In cattle and buffaloes, the right rear quarters are involved in higher percentages than involvement of other quarters alone or in combination. Mastitis can be triggered through injury or infection caused by various pathogens, including bacteria, viruses, algae, or fungi and these organisms can be categorised based on their pathogenesis, etiology or severity of infection (Qayyum et al., 2016) but majority of mastitis cases in dairy industry are due to bacterial infections (Cobirka et al. 2020).

\section{Teat to Floor Distance and Space allowance}

High prevalence of mastitis in cattle and buffaloes is observed with low teat to floor distance (Waage et al. 
2001; Svensson et al. 2006; Compton et al. 2007; Bhutto et al. 2010). There is no difference between mastitic and healthy animals for teat lesions. Space allowance has no effect on milk yield, live weight, body condition score, and lying; however prevalence of mastitis is indicated in cows kept in unhygienic straw yards at low space allowance (Fregonesi and Leaver 2001).

\section{Mastitis and Feeding system}

There is no difference between mastitic and healthy animals due to feeding system. However, lesions on udder, udder shape, use of oxytocin, calf suckling and hosing space showed difference between mastitic and healthy animals (cattle and buffaloes). The cases of mastitis are higher in animals (cattle +buffaloes) having lesions like udder edema, skin abrasion and inflammation, in animals having bowl or round shaped than cup shaped udder, in animals having cylindrical udder, in animals in which oxytocin is frequently used for milk let down, where calf suckling practice is made after milking of animals, in cases of stall feeding + grazing and in animals provided less space for housing.

\section{Miscellaneous}

The milk temperature does not show any difference between mastitic and health animals. The milk $\mathrm{pH}$, electrical conductivity, malondialdehyde and total dissolved solids are higher in milk from mastitic than that from healthy buffaloes. However, milk fat, milk yield, proteins, lactose and solids-not-fat (SNF) are lower for milk from mastitic than that from healthy animals. Increased risk of mammary infection is also related with increased live weight, increase in age at first calving, increase in parity, low milk flow rate and leaking of milk. The age, parity, tail size and lactation stage show no difference between mastitic and healthy buffaloes. However, live body weight, milk leakage, and udder depth show differences between mastitic and healthy buffaloes. The values for these variables are higher in mastitic than healthy buffaloes, except for teat floor distance which is lower in mastitic animals. Tail length is not associated with prevalence of mastitis.

\section{Histopathology}

Intra-mammary infusion of oyster glycogen increases milk leukocyte count six times and also increases protein and fat percentages, but reduces milk lactose concentration in lactating ewes. The infused mammary glands show increased damage or non-secretory epithelial cells along with three times increase in neutrophils, 1.3-fold plasma cells in the sub-epithelial stroma and 2.7-fold of neutrophils within the epithelial lining of alveoli. Decrease in milk yield is due to increase in somatic cells, along with loss of functional mammary cells, associated with leukocytosis. Secretory parenchyma of unbred healthy quarters is immature, showing small alveoli having limited luminal area and abundant inter-alveolar stromal area.
Staphylococcus aureus infected tissues are less developed with small alveolar epithelial and luminal areas and with additional inter-alveolar stroma than healthy quarters. Secretory activity is also reduced in quarters infected with Staphylococcus aureus. Presence of abscesses is also seen in quarters infected with Staphylococcus aureus. Leukocytic infiltration in mammary parenchyma and in cistern lining of infected quarter is higher than that of healthy quarters (Pacha et al. 2020). Alveolar diameter (short and long), number of alveoli, maximum and minimum short and long diameters and epithelial cell population of alveoli in infected cattle and buffaloes are lower than those in healthy animals.

Histopathology for both cattle and buffaloes reveals the atrophy of alveoli in udder tissues of different degree (mild, moderate or severe), cellular exudate in the lumen of the alveoli in varying amounts, broken alveoli, cellular infiltration in udder tissue including lymphocytes, monocytes and/or neutrophils in the parenchyma, cellular infiltration in teat tissue including lymphocytes, monocytes and/or neutrophils and the proliferation of connective tissues in infected animals.

Economic importance, Characterization of Mastitis, and Public Health Concerns

Various expenses due to any disease can create such conditions where culling becomes necessary. In dairy production, improved management and different control measures have greatly decreased the incidence and prevalence of contagious mastitic organisms. Inflammation of mammary tissue (mastitis) is a multifarious disease that affects dairy animals and causes huge economic losses through decreasing 3-5\% milk production and impairing its quality, which indicates serious risk to human health (Marjan et al. 2009; Freitas 2017; Jingar et al. 2017). While investigating the total expenses that are involved in mastitis prevention and its treatment, scientists have determined some strategies based on the direct impacts of the disease. In India, due to mastitis Rs. 16,072 million economic losses, along with $50 \%$ to $17.5 \%$ decrease in average milk production, have been reported. In Nili- Ravi buffaloes, mastitis decreases $438 \mathrm{~kg}$ milk of each animal by reducing 57 days lactation length (Yasir et al. 2020). Economic losses due to mastitis may be divided into lower milk production $(70 \%)$, discarded milk due to veterinary medication (8\%), and premature culling (14\%) (Barkema et al. 2006; Halasa et al. 2007; Cheng and Han 2020). The degree of production losses depends on causative agent, parity of lactating animal and lactation stage at which mammary glands infection occurs. In dairy animals, production loss is harsh when clinical mastitis occurs before peak milk yield due to S. aureus, Klebsiella and E. coli (Grohn et al. 2004; Wilson et al. 2004). However, subclinical mastitis occurring in late stage of lactation causes highest production loss (Bennedsgaard et al. 2003; Gonçalves et al. 2018).

Mastitis affects the milk quality, and it is also hazardous from the public health prospective. It also leads to an increased culling rate of dairy animals from the herd 
(Parker et al. 2007). The API Staph-kit system is excellent and accurate for the identification of Staphylococci. Various studies have shown its use in humans for the identification and confirmation of Staphylococcal species (Romanowski et al. 2021). The API Staph-kit system, which is urbanized for the detection of human Staphylococci, exactly identifies the bovine pathogensand indicates the variation in biochemical profile between animals and human pathogens (Adkins et al. 2017).

\section{REFERENCES}

Abera $\mathrm{M}$ et al., 2010. Isolation and identification of Staphylococcus aureus from bovine mastitic milk and their drug resistance patterns in Adama town, Ethiopia. Journal of Veterinary Medicine and Animal Health 2(3): 29-34.

Adkins PR and JR Middleton, 2018. Methods for diagnosing mastitis. Veterinary Clinics: Food Animal Practice 34: 479-491.

Adkins PRF et al., 2017. Species identification and strain typing of Staphylococcus agnetis and Staphylococcus hyicus isolates from bovine milk by use of a novel multiplex PCR assay and pulsed-field gel electrophoresis. Journal of Clinical Microbiology 55: 1778-1788.

Akers RM and Nickerson SC, 2011. Mastitis and its impact on structure and function in the ruminant mammary gland. Journal of Mammary Gland Biology and Neoplasia 16: 275-289.

Akersted $\mathrm{M}$ et al., 2007. Haptoglobin and serum amyloid $A$ in relation to the somatic cell count in quarter, cow composite and bulk tank milk samples. Journal of Dairy Research 74: 198-203.

Ali F et al., 2016. Milk somatic cell counts and some hemato-biochemical changes in sub-clinical mastitic dromedary she-camels (Camelus dromedarius). Pakistan Veterinary Journal 36: 405-408.

Ali L et al., 20o8. Bacteriology of mastitis in buffaloes in Tehsil Samundri district Faisalabad, Pakistan. Pakistan Veterinary Journal 28: 31-33.

Arshad M et al., 2006. Staphylococcal mastitis in bovines and some properties of Staphylococcal isolates. Pakistan Veterinary Journal 26: 20-22.

Ashmead HD and RA Samford, 2004. Effects of metal amino acid chelates or inorganic minerals on three successive lactations in dairy cows. International Journal of Applied Research in Veterinary Medicine 2: $181-188$.

Ashraf $\mathrm{A}$ and $\mathrm{M}$ Imran, 2020. Causes, types, etiological agents, prevalence, diagnosis, treatment, prevention, effects on human health and future aspects of bovine mastitis. Animal Health Research Reviews 21: 36-49.

Ávila $G$ et al., 2020. In vitro effects of conjugated linoleic acid (CLA) on inflammatory functions of bovine monocytes. Journal of Dairy Science 103: 8554-8563.

Bachay HA et al., 2011. Subclinical bovine mastitis in Muzaffar Garh district of Punjab (Pakistan). Journal of Animal and Plant Sciences 21: 16-19.

Barkema HW et al., 1999. Physiology and management practices associated with the incidence rate of clinical mastitis. Journal of Dairy Science 82: 1643-1654.
Barkema HW et al., 2006. The role of cow, pathogen, and treatment regimen in the therapeutic success of bovine Staphylococcus aureus mastitis. Journal of Dairy Science 89: 1877-1895.

Batavani RA et al., 2007. The effect of subclinical mastitis on milk composition in dairy cows. Iranian Journal of Veterinary Research 8: 205-210.

Benites NR et al., 2002. Aetiology and histopathology of bovine mastitis of espontaneous occurrence. The Journal of Veterinary Medicine, Series B 49:366-370.

Bennedsgaard TW et al., 2003. Eleven years of organic dairy production in Denmark: Herd health and production related to time of conversion and compared to conventional production. Livestock Production Science 80: 121-131.

Beytut E et al., 2009. Pathological, immunohistochemical, and bacteriological findings in the mammary glands and supramammary lymph nodes of cows with a history of abortion due to Brucella abortus. Turkish Journal of Veterinary and Animal Sciences 33: 37-43.

Bhakat C, 2019. Interdependence and distribution of subclinical mastitis and intra-mammary infection among udder quarters in Jersey crossbred cows. International Journal of Agriculture Sciences 9: 42354237.

Bhutto AL et al., 2010. Udder shape and teat-end lesions as potential risk factors for high somatic cell counts and intra-mammary infections in dairy cows. The Veterinary Journal 183: 63-67.

Bradley A, 2002. Bovine mastitis: An evolving disease. Veterinary Journal 164: 116- 128.

Bradley AJ and MJ Green, 2001. Adaptation of Escherichia coli to the bovine mammary gland. Journal of Clinical Microbiolology 39: 1845-1849.

Breen JE et al., 2009. Quarter and cow risk factors associated with a somatic cell count greater than 199,000 cells per milliliter in United Kingdom dairy cows. Journal of Dairy Science 92: 3106-3115.

Capuco AV et al., 2003. Lactation persistency: Insights from mammary cell proliferation studies. Journal of Animal Science 81: 18-31.

Cardoso GJ et al., 2020. Expression of selected lipogenic genes and fatty acid transporters changes across stages of lactation in dairy ewes. Tropical and Subtropical Agroecosystems 23: Article \# 94.

Cerqueira JL et al., 2018. How is the association of teatend severe hyperkeratosis on udder health and dairy cow behavior? Veterinary Medicine Review 169: 30-37.

Chen P et al., 2021. Characterization of Streptococcus lutetiensis isolated from clinical mastitis of dairy cows. Journal of Dairy Science 104: 702-714.

Cheng RJ et al., 2010. Investigation of $\mathrm{N}$ isotopic fractionation in dairy cows using milk samples collected at the morning and afternoon milkings. Proceedings of the New Zealand Society of Animal Production 70: 65-66.

Cheng WN and SG Han, 2020. Bovine mastitis: Risk factors, therapeutic strategies and alternative treatments-A review. Asian-Australasian Journal of Animal Sciences 33: 1699. 
Chrystal MA et al., 2001. Heritability of teat-end shape and the relationship of teat-end shape with somatic cell score for an experimental herd of cows. Journal of Dairy Science 84: 2549-2554.

Cobirka $\mathrm{M}$ et al., 2020. Epidemiology and classification of mastitis. Animals 10: 2212.

Compton CW et al., 2007. Risk factors for peripartum mastitis in pasture-grazed dairy heifers. Journal of Dairy Science 90: 4171-4180.

Cortinhas CS et al., 2010. Antioxidant enzymes and somatic cell count in dairy cows fed with organic source of zinc, copper and selenium. Livestock Science 127: 84-87.

Costa EO, 1998. Importance of mastitis in the country's dairy production. Journal of Continuing Education in Veterinary Medicine and Animal Science of CRMV-SP, 1: 3-9.

da Silva Soares B et al., 2021. Molecular characterization and genetic diversity of Staphylococcus aureus isolates of dairy production farms in Rio de Janeiro, Brazil. Brazilian Journal of Veterinary Medicine 43: eoo112oeoo1120.

Damm M et al., 2017. Differential somatic cell count-A novel method for routine mastitis screening in the frame of Dairy Herd Improvement testing programs. Journal of Dairy Science 100: 4926-4940.

Depreester E et al., 2017. Flow cytometric assessment of myeloperoxidase in bovine blood neutrophils and monocytes. Journal of Dairy Science 100: 7638-7647.

Derakhshani $\mathrm{H}$ et al., 2018. Microbiota of the bovine udder: Contributing factors and potential implications for udder health and mastitis susceptibility. Journal of Dairy Science 101: 10605-10625.

Derakhshani $\mathrm{H}$ et al., 2020. Composition and cooccurrence patterns of the microbiota of different niches of the bovine mammary gland: Potential associations with mastitis susceptibility, udder inflammation and teat-end hyperkeratosis. Animal Microbiome 2: 1-17.

DeVliegher S et al., 2005. Asociation between somatic cell count in early lactation and culling of dairy heifers using Cox frailty models. Journal of Dairy Science 88: $560-568$.

Dhakal IP, 2006. Normal somatic cell count and subclinical mastitis in Murrah buffaloes. Journal of Veterinary Medicine, Series B 53: 81-86.

Djabri B et al., 2002. Quarter milk somatic cell count in infected dairy cows: A meta-analysis. Veterinary Research 33: 335-357.

Durr JW et al., 2008. Milk losses associated with somatic cell counts per breed, parity and stage of lactation in Canadian dairy cattle. Livestock Science 117: 225-232.

Eckersall PD et al., 2001: Acute phase proteins in serum and milk from dairy cows with clinical mastitis. Veterinary Record 148: 35-41.

Elsayed EH et al., 2009. Histological and histochemical study on mammary gland of Damascus goats through stages of lactation. Small Ruminant Research 85: 11-17.

Enjalbert $F$ et al., 20o6. Effects of copper, zinc and selenium status on performance and health in commercial dairy and beef herds, retrospective study.
Journal of Animal Physiology and Animal Nutrition 90: 459-466.

Fabris TF et al., 2020. Effect of heat stress during the early and late dry period on mammary gland development of Holstein dairy cattle. Journal of Dairy Science 103: 8576-8586.

Fakhar-uz-Zaman MS et al., 2009. Estimation of protein, total leukocyte count and differential leukocyte count in the blood and milk of subclinically mastitic buffaloes. Pakistan Journal of Zoology Supplementary Series, No.9, pp: 115-118.

Fregonesi JA and JD Leaver, 2001. Behaviour, performance and health indicators of welfare for dairy cows housed in strawyard or cubicle systems. Livestock Production Science 68: 205-216.

Freitas FAD, 2017. Milk proteinogram of cows with subclinical mastitis as a function of somatic cell score and isolated microorganisms identified by conventional microbiology. Masters' Thesis: School of Veterinary and Animal Science, Federal University of Goiás, Brazil.

Gargouri A et al., 20o8. Total and differential bulk cow milk somatic cell counts and their relation with lipolysis. Livestock Science 113: 274-279.

Gleeson DE et al., 2004. Effect of teat hyperkeratosis on somatic cell counts of dairy cows. International Journal of Applied Research in Veterinary Medicine 2: $115-122$.

Gonçalves JL et al., 2018. Milk losses associated with somatic cell counts by parity and stage of lactation. Journal of Dairy Science 101: 4357-4366.

Green MJ et al., 2004. The use of Markov chain Monte Carlo for analysis of correlated binary data: Patterns of somatic cells in milk and the risk of clinical mastitis in dairy cows. Preventive Veterinary Medicine 64: 157174 .

Griffiths L et al., 2007. Effects of supplementing complexed zinc, manganese, copper and cobalt on lactation and reproductive performance of intensively grazed lactating dairy cattle on the South Island of New Zealand. Animal Feed Science Technology 137: 69-83.

Grohn YT et al., 2004. Effect of pathogen-specific clinical mastitis on milk yield in dairy cows. Journal of Dairy Science 87: 3358-3374.

Guarín JF et al., 2017. Association of anatomical characteristics of teats with quarter-level somatic cell count. Journal of Dairy Science 100: 643-652.

Guler L et al., 2005. Antimicrobial susceptibility and coagulase gene typing of Staphylococcus aureus isolated from bovine. Journal of Dairy Science 83: 3149-3154.

Halasa T et al., 2007. Economic effects of bovine mastitis and mastitis management: A review. Veterinary Quarterly 29: 18-31.

Hamann J, 2002. Milk quality and udder health in relation to modern milking. In: Recent Developments and Perspectives in Bovine Medicine, XXII World Buiatrics Congress, Hannover August 18-23, pp: 334-345.

Hussain R et al., 2012. Changes in some biochemical parameters and somatic cell counts in the milk of 
buffalo and cattle suffering from mastitis. Pakistan Veterinary Journal 32: 418-421.

Hussain R, 2011. Histo-morphometry, epidemiology and molecular pathobiology of mastitis in buffaloes and cows. Doctoral dissertation, University of Agriculture Faisalabad, Pakistan.

Ibrahim AM et al., 2011. Epidemiology and microbiological studies on mastitis in she-camels. Intantional Journal of Microbiological Research 2: 18-27.

Javid F et al., 2018. Molecular typing of Staphylococcus aureus based on coagulase gene. Veterinary World 11: 423.

Jingar SC et al., 2017. Economic losses due to clinical mastitis in cross-bred cows. Journal of Dairy \& Veterinary Sciences 3: 1-6.

Kellogg DW et al., 2004. Effect of feeding zinc methionine complex on milk production and somatic cell count of dairy cattle: twelve-trial summary. The Professional Animal Scientist 20: 295-301.

Khatun M et al., 2019. Suitability of somatic cell count, electrical conductivity, and lactate dehydrogenase activity in foremilk before versus after alveolar milk ejection for mastitis detection. Journal of Dairy Science 102: 9200-9212.

Kirkeby $\mathrm{C}$ et al., 2021. Dynamics of somatic cell count (SCC) and differential SCC during and following intramammary infections. Journal of Dairy Science 104: $3427-3438$.

Kitchen B, 1981. Review of the progress of dairy science: Bovine mastitis: milk compositional changes and related diagnostic tests. Journal of Dairy Science 48: 167-188.

Klaas IC et al., 2004. Systematic clinical examinations for identification of latent udder health types in Danish dairy herds. Journal of Dairy Science 87: 1217-1228.

Kumar $\mathrm{M}$ et al. 2007. Investigations on prevalence and oxidative stress aspects of mastitis in buffaloes. Italian Journal of Animal Science (Supplement 2): 978-979.

Lakshmi $\mathrm{K}$ et al., 2009. Buffalo mastitis - risk factors. Buffalo Bulletin 3: 135-137.

Leitner G et al., 200oa. Milk leukocyte populations in heifers free from udder infection. Journal of Veterinary Medicine 47: 133-138.

Leitner $G$ et al., 2007. Involution stage of the bovine mammary gland biological implications obstructs pregnancy. Israel Journal of Veterinary Medicine 62:3- 4.

Lindmark-Mansson $\mathrm{H}$ et al., 2006. Relationship between somatic cell count, individual leukocyte populations and milk components in bovine udder quarter milk. International Dairy Journal 16: 717-727.

Mabrook MF and MC Petty, 2003. Effect of composition on the electrical conductance of milk. Journal of Food Engineering 60: 321-325.

Malik TA et al., 2018. Somatic cells in relation to udder health and milk quality-a review. Journal of Animal Health and Production 6(1): 18-26.

Manocha SL et al., 2017. Studies on isolation of pathogens causing sub-clinical mastitis in cross bred dairy cattle and their antibiogram. Brain Research 400:348-352.

Marjan JT et al., 2009. Induction of Staphylococcus aureus-specific IgA and agglutination potency in milk of cows by mucosal immunization. Vaccine 27: 40014009.

Mehrzad J et al., 2002. Blood and milk neutrophil chemiluminescence and viability in primiparous and pluriparous dairy cows during late pregnancy around parturition and early lactation. Journal of Dairy Science 85: 3268-3276.

Misk $\mathrm{N}$ et al., 2018. A retrospective study of surgical affections of mammary glands in cattle and buffaloes and their management in the field. Journal of Veterinary Medical Science 8o(10): 1576-1583.

Moradi $\mathrm{M}$ et al., 2020. The relationship between milk somatic cell count and cheese production, quality and safety: A review. International Dairy Journal 113: 104884.

Moroni $\mathrm{P}$ et al., 2005. Risk factors for intramammary infections and relationship with somatic-cell counts in Italian dairy goats. Preventive Veterinary Medicine 69: 163-173.

Moroni P et al., 2006. Relationship between somatic cell count and intramammary infection in buffaloes. Journal of Dairy Science 89: 998-1003.

Nagase $\mathrm{N}$ et al., 2002. Characterisation of Staphylococcus aureus strains isolated from bovine mastitis in Japan. Journal of Veterinary Medical Science 64: 1169-1172.

Nickerson SC, 2009. Control of heifer mastitis: Antimicrobial treatment-An overview. Veterinary Microbiology 134: 128-135.

Nyman A-K et al., 2007. Risk factors associated with the incidence of veterinary-treated clinical mastitis in Swedish dairy herds with a high milk yield and a low prevalence of subclinical mastitis. Preventive Veterinary Medicine 78: 142-160.

Nyman A-K et al., 2009. Management practices associated with udder health of first-parity dairy cows in early lactation. Preventive Veterinary Medicine 88: 138-149.

Okkema $\mathrm{C}$ and $\mathrm{T}$ Grandin, 2021. Graduate Student Literature Review: Udder edema in dairy cattle-A possible emerging animal welfare issue. Journal of Dairy Science 104(6): 7334-7341.

Oliszewski $\mathrm{R}$ et al., 2002. Assessment of $\beta$-glucuronidase levels in goat's milk as an indicator of mastitis: Comparison with other mastitis detection methods. Journal of Food Protection 65: 864-866.

Oliver SP and Sordillo LM., 1988. Udder health in the periparturient period. Journal of Dairy Science 71: 2584-2606.

Osteras $\mathrm{O}$, 200o. The cost of mastitis - an opportunity to gain more money. In: Proceedings of the British Mastitis Conference-20oo, Shepton Mallet, UK, pp: 67-77.

Oviedo-Boyso J et al., 2007. Innate immune response of bovine mammary gland to pathogenic bacteria responsible for mastitis. Journal of Infection 54: 399409.

Paape MJ et al., 2007. Monitoring goat and sheep milk somatic cell counts. Small Ruminant Research 68: 114125.

Pacha PA et al., 2020. Virulence profiles of Staphylococcus aureus isolated from bulk tank milk and adherences 
on milking equipment on Chilean dairy farms. Journal of Dairy Science 103: 4732-4737.

Parker KI et al., 2007. Management of dairy heifers and its relationships with the incidence of clinical mastitis. New Zealand Veterinary Journal 55: 206-216.

Piepers S et al., 2009. Impact of intramammary infections in dairy heifers on future udder health, milk production and culling. Veterinary Microbiology 134: 113-120.

Pillai SR et al., 2001. Application of differential inflammatory cell count as a tool to monitor udder health. Journal of Dairy Science 84: 1413-1420.

Pyorala S and S Taponen, 2009. Coagulase-negative Staphylococci: Emerging mastitis pathogens. Veterinary Microbiology 134:3-8.

Qayyum A et al., 2016. Investigation of milk and blood serum biochemical profile as an indicator of subclinical mastitis in Cholistani cattle. Pakistan Veterinary Journal 36: 275-279.

Qayyum A et al., 2016. Prevalence and association of possible risk factors with sub-clinical mastitis in Cholistani cattle. Pakistan Journal of Zoology 48: 519-525.

Riollet $C$ et al., 200o. Kinetics of cells and cytokines during immune-mediated inflammation in the mammary gland of cows systemically immunized with Staphylococcus aureus alpha-toxin. Inflammation Research 49: 486-496.

Romanowski JE et al., 2021. Identification of coagulase negative Staphylococci isolated from endophthalmitis using Biolog GEN III Microplate, API Staph Ident, and DNA sequencing. Investigative Ophthalmology \& Visual Science 62(8): 1949.

Santos OCDS et al., 2009. Identification of coagulasenegative Staphylococci from bovine mastitis using RFLP-PCR of the groEL gene. Veterinary Microbiology 130: 134-140.

Schukken YH et al., 1994. Genetic impact on the risk of intramammary infection following Staphylococcus aureus challenge. Journal of Dairy Science 77: 639-647.

Schukken YH et al., 2003. Monitoring udder health and milking quality using somatic cell counts. Veterinary Research 34: 579-596.

Schwarz D et al., 2020. Investigation of dairy cow performance in different udder health groups defined based on a combination of somatic cell count and differential somatic cell count. Preventive Veterinary Medicine 183: 105-123.

Shah A et al., 2017. Somatic cell alteration in healthy and mastitic milk of sheep and goats. Journal of Entomology and Zoology Studies 5: 27-33.

Silanikove N, et al., 2006. Physiological role of indigenous milk enzymes: An overview of an evolving picture. International Dairy Journal 16: 533-545.

Slettbakk T et al., 1995. Impact of milking characteristics and morphology of udder and teats on clinical mastitis in first and second lactation Norwegian cattle. Preventive Veterinary Medicine 24: 235-244.

Soliman I, 2018. Role of buffalo production in sustainable development of rural regions. In: Sustainable Agriculture and Food Security, Springer, CHAM pp: 21-38.

Sordillo LM, 2018. Mammary gland immunobiology and resistance to mastitis. The Veterinary Clinics of North
America: Food Animal Practice 34: 507-523.

Sorensen MK et al., 20oo. Udder conformation and mastitis resistance in Danish first lactation cows: Heritabilities, genetic and environmental correlations. Acta Agriculturae Scandinavica. Section A, Animal Science 50: 72-82.

Stocco G et al., 2020. Differential somatic cell count as a novel indicator of milk quality in dairy cows. Animals 10: 753 .

Suriyasathaporna S et al., 2006. Higher somatic cell counts resulted in higher malondialdehyde concentration in raw cow's milk. International Dairy Journal 16: 1088-1091.

Svensson C et al., 2006. Effects of housing, management, and health of dairy heifers on first-lactation udder health in southwest Sweden. Journal of Dairy Science 89: 1990-1999.

Talukder M and HM Ahmed, 2017. Effect of somatic cell count on dairy products: A review. Asian Journal of Medical and Biological Research 3: 1-9.

Taponen S and S Pyorala, 2009. Coagulase-negative Staphylococci as cause of bovine mastitis-Not so different from Staphylococcus aureus. Veterinary Microbiology 134: 29-36.

Tiezzi F et al., 2020. Heritability of teat condition in Italian Holstein Friesian and its relationship with milk production and somatic cell score. Animals 10(12): 2271. https://doi.org/10.339o/ani10122271.

Tomazi T et al., 2018. Association of herd-level risk factors and incidence rate of clinical mastitis in 20 Brazilian dairy herds. Preventive Veterinary Medicine 161: 9-18.

Unnerstad HE et al., 2009. Microbial aetiology of acute clinical mastitis and agent-specific risk factors. Veterinary Microbiology 137: 90-97.

Waage $\mathrm{S}$ et al., 20o1. Case-control study of risk factors for clinical mastitis in postpartum dairy heifers. Journal of Dairy Science 84: 392-399.

Waller PK et al., 2009. Incidence of mastitis and bacterial findings at clinical mastitis in Swedish primiparous cows. Influence of breed and stage of lactation. Veterinary Microbiology 134: 89-94.

Wang SC et al., 2009. Distribution of superantigenic toxin genes in Staphylococcus aureus isolates from milk samples of bovine subclinical mastitis cases in two major diary production regions of China. Veterinary Microbiology 137: 276-281.

Wieland $\mathrm{M}$ et al., 2020. A randomized trial to study the effect of automatic cluster remover settings on milking performance, teat condition, and udder health. Journal of Dairy Science 103: 3668-3682.

Wilson DJ et al., 2004. Effect of clinical mastitis on the lactation curve: A mixed model estimation using daily milk weights. Journal of Dairy Science 87: 2073-2084.

Yasir MA et al., 2020. Factors affecting reproductive and productive efficiency of Nili Ravi buffaloes (Bubablus bubalis) in Punjab, Pakistan. Journal of Animal and Plant Sciences 30: 568-575.

Zavadilová L et al., 2020. Genetic parameters for clinical mastitis in Czech Holstein cattle. Czech Journal of Animal Science 65: 463-472. 